\title{
Development and validation of the scale of knowledge, comfort and attitudes of physiotherapy students towards human sexuality (SKCAPS)
}

\author{
Construção e validação da escala de conhecimento, \\ conforto e atitudes de acadêmicos de fisioterapia \\ frente à sexualidade humana (ECCAFS)
}

\section{Priscilla Geraldine Wittkopf, Fernando Luiz Cardoso, Fabiana Flores Sperandio*}

Universidade do Estado de Santa Catarina (UDESC), Florianópolis, SC, Brazil

\begin{abstract}
Introduction: Recent studies with Physiotherapy students pointed out for attitudes and conflicting perceptions on their learning process during the phase that precedes the clinical practice. One of those aspects is the human sexuality that appears in the close physical contact that demands Physiotherapists professional practices. Objective: To build up the first educational/research instrument that evaluates the knowledge, the comfort and the attitudes of Physiotherapy undergraduate students (SKCAPS). Materials and methods: From the literature we extracted three dimensions: knowledge, comfort and attitudes. Initially 50 items were created distributed in the three dimensions that went under the content evaluation, 47 items survived from this
\end{abstract}

* PGW: MSc, e-mail: grdpri@hotmail.com

FLC: PhD, e-mail: fernandocardoso.ph.d.lagesc@gmail.com

FFS: PhD, e-mail: fabi@intercorp.com.br 
process and integrate the first version of SKCAPS. In empiric terms the intern coherence and the reliability of the instrument were tested in 248 students. Results: The exploratory factorial analysis carried 37 items in 4 factors that explain $68 \%$ of the total variance of the answers of the subjects and that confirmed the proposed dimensions. The dimension comfort became separated in comfort and discomfort. The SKCAPS presented good reliability in terms of intern consistence alpha 0.861 . Finally, the instrument was administered to 30 Physiotherapy students for evaluation of clarity following the exclusion of two items that resulted in averages below 8.5. Conclusions: With the aim of improve the teaching/learning process, we propose the SKCAPS as the first worth and reliable instrument to evaluate the knowledge, the comfort, the discomfort and the attitudes regard of human sexuality among Physiotherapy students.

Keywords: Knowledge. Attitude. Physiotherapy. Sexuality.

\section{Resumo}

Introdução: Estudos recentes com estudantes de Fisioterapia apontam para atitudes e percepções conflituosas sobre seu processo de aprendizagem durante a fase que antecede a prática clínica. Um desses aspectos trata-se da sexualidade humana, que surge no contato físico que exige a prática profissional. Objetivo: Apresentar e descrever as principais etapas da elaboração de uma escala para avaliação de conhecimento, conforto, e atitudes de acadêmicos de fisioterapia frente à sexualidade humana (ECCAFS). Materiais $\boldsymbol{e}$ métodos: A partir da literatura extraíram-se três domínios/dimensões: conhecimento, conforto e atitudes. Inicialmente 50 itens foram criados e distribuídos nas três dimensões, que passaram por uma avaliação de conteúdo, selecionou-se 47 itens que integraram a primeira versão da ECCAFS. Em termos empíricos, testou-se a coerência interna e a confiabilidade do instrumento em 248 estudantes. Resultados: A análise fatorial exploratória carregou 37 itens em 4 fatores, que explicam 68\% da variância total das respostas dos sujeitos e que confirmaram as dimensões propostas. A dimensão conforto dividiu-se em conforto e desconforto. A ECCAFS apresentou boa confiabilidade em termos de consistência interna alfa 0,861. Por fim, o instrumento foi aplicado a 30 estudantes de Fisioterapia para avaliação da clareza seguindo a exclusão de dois itens que resultaram em médias inferiores a 8,5. Conclusões: Com o objetivo de facilitar o processo de ensino-aprendizagem, propõe-se a ECCAFS como o primeiro instrumento válido e confiável para avaliar o conhecimento, o conforto, o desconforto e as atitudes de acadêmicos de Fisioterapia frente à sexualidade humana.

Palavras-chave: Conhecimento. Atitude. Fisioterapia. Sexualidade.

\section{Introduction}

Human sexuality cannot be reduced to the sexual act, aiming pleasure in addition to reproduction; therefore it cannot be understood only by knowing the sexual anatomy and physiology, being also important to consider the psychological and cultural context in which each individual lives (1). Thus, it was observed that sexuality is inseparable from other aspects of life for being a basic human need and, consequently, it should receive due attention from health professionals (2).

For professionals to be able to meet all patient needs also in relation to the scope of sexuality, their training should include the acquisition of knowledge, learning of specific psychomotor skills and, in particular, the development of appropriate affective skills required to the exercise of the chosen profession (3).

However, when analyzing studies addressing sexuality in higher education, it was observed that some students in the health area feel embarrassed and unprepared to deal with beliefs, myths and taboos surrounding their patients sexuality $(4,5)$. It appears that this topic is often approached in a restrictively and superficial way (6), compromising the proper understanding of the subject and, consequently, the construction of the knowledge of the future health professionals $(7,8)$. 
It is known that knowledge is related to comfort and attitude, since it is the basis for students and professionals to feel comfortable in dealing with their patients, helping them to take safer attitudes, reflecting in professional actions (9). Attitudes are part of the "hypothetical constructs" that determine how individuals behave in relation to others, evaluating, most of the time, feelings, behaviors and choices. Thus, many studies have shown that attitudes are powerful behavior predictors $(9,10)$.

It is noteworthy that many young students in universities start adopting different behaviors, often influenced by the new social and academic environment, as well as by greater autonomy and freedom, which are typical of this population (11). It is known that students will be the future health professionals and that they should act as educators and motivators of performance and models of general health (12).

Given the above, recent studies with Physiotherapy undergraduate students $(13,14)$ have shown conflicting attitudes and perceptions about their learning process, as well as unhealthy behaviors during the phase prior to clinical practice. Even within the academic environment, human sexuality is still treated as taboo by many professionals $(4,5)$. Whereas Physiotherapists develop a work with intense physical contact with their patients, it is expected that difficulties arise from this interaction.

In activities involving humans, clear and positive attitudes towards sexuality issues should be part of subjects on professional and academic training (15), since there are about 562 Physiotherapy courses in Brazil according to the Ministry of Education (16) and 166,000 physiotherapists (17).

Thus, the aim of this study was to present and describe the main stages in the preparation of a scale to evaluate knowledge, comfort and attitudes of Physiotherapy undergraduate students towards human sexuality (SKCAPS) (Annex 1).

\section{Materials and methods}

\section{Instrument development}

As can be seen in Figure 1, a literature search for articles indexed in PubMed, Medline, SciELO and Lilacs databases published in English and Portuguese was firstly performed. The aim of this search was to find existing scales to assess knowledge, comfort and attitudes of undergraduate students towards human sexuality. The instrument called Knowledge, Comfort, Approach and Attitudes towards Sexuality Scale (KCAASS) developed by Kendall et al. (18) was used to define domains/dimensions for the research to develop this instrument: knowledge, attitudes and comfort, which was subdivided into comfort and discomfort were finally selected.

Then, questions were formulated for the three domains, as well as their response scales and scores.

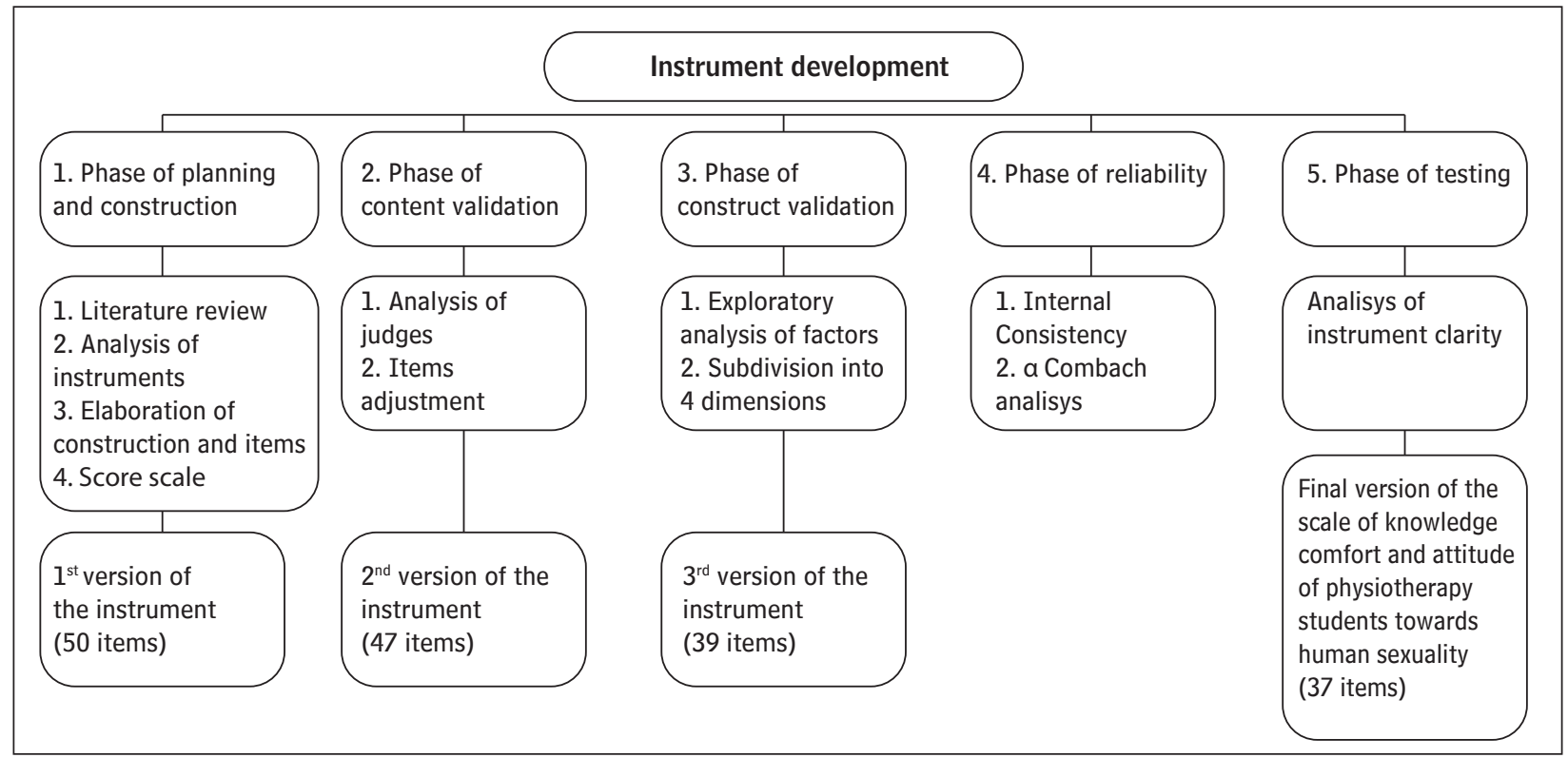

Figure 1 - Instrument development stages 
After this stage, the first version of the instrument consisting of 50 items was presented.

\section{Content validation}

The first version of the instrument was submitted to content analysis by a group of six experts, professors of physiotherapy and human sexuality area, which were invited for mastering the contents involved and for having professional experience in issues related to the research theme. The experts reviewed the items for consistency, representativeness, relevance and clarity according to Pasquali (19).

This phase included a content review matrix designed to evaluate the level of agreement of experts in relation to items. The analysis of this stage used the Content Validity Index (CVI), where experts responded on a Likert scale from one to four. The higher the score, the more adequate was the question in relation to items. Questions obtaining CVI less than 0.8, i.e., level of agreement among judges less than $80 \%$ were excluded from the questionnaire or adjusted according to suggestions and reassessed by all six experts $(19,20,21)$.

At this stage, the instrument with 47 questions was applied to 10 undergraduate physiotherapy students attending the last semester who cooperated with suggestions about the content of items. Thus, based on the suggestions of this group of students, it was possible to improve the formulation of many items in order to improve the suitability of the instrument for its subsequent application in the target population.

\section{Data collection procedures}

The second version of the instrument with 47 questions was applied to 248 physiotherapy students of four different universities of Florianópolis. Study participants aged 22.2 years on average (5.3) and females were $82 \%$ of respondents. The study was approved by the Research Ethics Committee of the State University of Santa Catarina (process No. 167,853). The free and informed consent form was applied according to legislation. The return of the completed instrument was accompanied by the consent form.

The scale was presented to subjects in a single book containing 47 items divided into four domains: D1: Knowledge, D2: Comfort, D3: Discomfort, D4: Attitude. The first three domains followed the Likert scale with zero score (no knowledge / comfort / discomfort) to four (excellent knowledge / comfort / discomfort). The fourth domain was also based on the Likert scale from zero (completely agree) to five (completely disagree).

\section{Psychometric analysis of the instrument}

To validate psychometric instruments some fundamental techniques are used including the determination of the content validity (22). Initially, the construct validity was performed, which consists of verifying whether the items are, in fact, representing the psychological construct to be measured. The instrument construct validity was verified by factor analysis. To check the adequacy of data to this analysis, the Keiser-Meyer Olkin index (KMO) was used, which is a measure of the factorability of correlation matrices, in which the factor analysis is based. Then, the Bartlett's sphericity test was used to verify if data met the sphericity prerequisite (23).

Factor analysis was performed taking into account the principal components and analysis of factor loadings. To determine the number of factors to be retained, criterion of eigenvalues above 1 was used. Then, orthogonal rotation was used through the varimax method. Questions with factor loadings lower than 0.4 were considered little significant and were excluded from the instrument.

To complete the stage of psychometric analysis, reliability validation was performed in terms of internal consistency. Internal consistency was assessed by Cronbach's Alpha in all subjects based on the minimum value of 0.60 (23).

Finally, the final version of the scale with 39 questions was judged as for its clarity by 30 Physiotherapy undergraduate students. Participants were instructed to assign score from zero to ten for each question, where zero meant that the question was unclear and ten very clear. The analysis was performed by using mean and standard deviation where questions with an average score of less than 8.5 would be excluded from the instrument.

\section{Results}

According to content validation procedures, three of the 50 items were excluded from the original 
version. The reason for the exclusion was the reduced agreement among judges. Three items were excluded: a) fertility procedures (CVI $=0.5)$; b) professional methods to work with sexual rehabilitation $(\mathrm{CVI}=0.5)$; ) I feel very uncomfortable if the patient touches my breast or other intimate part (CVI $=0.5$ ). These items were judged by $50 \%$ of experts as not representative, relevant and clear for this construct.

Regarding construct validity for the factor analysis, KMO index of 0.843 and significant Bartlett's sphericity test $(\mathrm{p}<0.001)$ were obtained, indicating that the correlation matrix is not an identity matrix. Together, these indicators ensured that the data set has the necessary prerequisites for factor analysis (Table 1).

In relation to the construct validity, the designed dimensionality was proved, and of the 47 items, only 8 failed to adequately load the previously entered domains due to conceptual inadequacy. Thus, 4 domains version explained $68 \%$ of variance. Exploratory factor analysis of data suggested the extraction of factors with loads above 0.40 with the aid of the "Principal axis analysis" method.

Table 1 - Factor analysis from the extraction of the knowledge domain items

\begin{tabular}{|c|c|}
\hline Item $a=0.856$ & Factor 1 \\
\hline Sexuality during puerperium & 0.789 \\
\hline Sexuality during menopause & 0.700 \\
\hline Sexuality with urinary incontinence & 0.682 \\
\hline $\begin{array}{l}\text { Specific terms: dyspareunia, vaginismus, } \\
\text { anorgasmia etc. }\end{array}$ & 0.641 \\
\hline Sexuality during pregnancy & 0.639 \\
\hline $\begin{array}{l}\text { Sexuality with physical disability (paraplegia, } \\
\text { hemiplegia etc.) }\end{array}$ & 0.638 \\
\hline $\begin{array}{l}\text { Risks of sexual activity for the } \\
\text { cardiovascular system }\end{array}$ & 0.614 \\
\hline $\begin{array}{l}\text { Techniques and resources to work with } \\
\text { sexual rehabilitation }\end{array}$ & 0.609 \\
\hline Sexual anatomy and physiology & 0.533 \\
\hline $\begin{array}{l}\text { Accessories, devices and drugs to achieve } \\
\text { erections and/or vaginal lubrication }\end{array}$ & 0.512 \\
\hline Methods for male and female contraception & 0.466 \\
\hline Sexuality during adolescence & 0.409 \\
\hline
\end{tabular}

The first factor extracted was the domain Knowledge with 12 items (Table 1). The second factor extracted was Comfort, composed of 12 items (Table 2). Then, the third factor extracted was domain discomfort, with 7 items (Table 3). The fourth and last factor extracted was domain Attitudes, with 8 items (Table 4). The items that did not load in any of the four factors mentioned above or items belonging to domains that did not load were excluded from the instrument.

Table 2 - Factor analysis from the extraction of the comfort domain items

\begin{tabular}{lc}
\hline Item $\mathbf{a}=\mathbf{0 . 9 5 5}$ & Factor $\mathbf{2}$ \\
\hline $\begin{array}{l}\text { Sexuality with physical disability (paraplegia, } \\
\text { hemiplegia etc.) }\end{array}$ & 0.861 \\
$\begin{array}{l}\text { Sexuality with urinary incontinence } \\
\text { Techniques and resources to work with sexual } \\
\text { rehabilitation }\end{array}$ & 0.855 \\
$\begin{array}{l}\text { Sexuality during menopause } \\
\text { Sexuality during pregnancy }\end{array}$ & 0.844 \\
$\begin{array}{l}\text { Sexuality during puerperium } \\
\text { Specific terms: dyspareunia, vaginismus, } \\
\text { anorgasmia etc. }\end{array}$ & 0.842 \\
$\begin{array}{l}\text { Risks of sexual activity for the cardiovascular } \\
\text { system }\end{array}$ & 0.841 \\
$\begin{array}{l}\text { Sexuality during adolescence } \\
\text { Accessories, devices and drugs to achieve } \\
\text { erections and/or vaginal lubrication }\end{array}$ & 0.834 \\
$\begin{array}{l}\text { Methods for male and female contraception } \\
\text { Sexual anatomy and physiology }\end{array}$ & 0.823 \\
\hline
\end{tabular}

Table 3 - Factor analysis from the extraction of the discomfort domain items

\begin{tabular}{lc} 
& (To be continued) \\
\hline Item $\mathbf{a}=\mathbf{0 . 8 1 0}$ & Factor $\mathbf{3}$ \\
\hline $\begin{array}{l}\text { How would you feel if you noted that the } \\
\text { patient of the opposite sex had an erection or } \\
\text { became sexually aroused during treatment? }\end{array}$ & 0.830 \\
How would you feel if you noted that the & \\
patient of the same sex had an erection or & 0.802 \\
became sexually aroused during treatment? & \\
$\begin{array}{l}\text { How would you feel if a patient of the opposite } \\
\text { sex touched your breast/penis or other intimate }\end{array}$ & 0.746 \\
part? & \\
\hline
\end{tabular}


Table 3 - Factor analysis from the extraction of the discomfort domain items

(Conclusion)

\begin{tabular}{lc}
\hline Item $a=0.810$ & Factor $\mathbf{3}$ \\
\hline $\begin{array}{l}\text { How would you feel if a patient of the same } \\
\text { sex touched your breast/penis or other intimate }\end{array}$ & 0.721 \\
part? & \\
How would you feel if a patient revealed & \\
abnormal sexual behaviors such as sex with & 0.701 \\
dead or animals etc.? & \\
How would you feel if a patient of the same & 0.607 \\
sex invited you for a date? & \\
How would you feel if a patient of the opposite & 0.449 \\
sex invited you for a date? & \\
\hline
\end{tabular}

Table 4 - Factor analysis from the extraction of the attitude domain items

\begin{tabular}{lc}
\hline Item a $\mathbf{0 . 7 2 9}$ & Factor 4 \\
\hline $\begin{array}{l}\text { I consider that it is duty only of physicians } \\
\text { and/or nurses to guide patients about sexual }\end{array}$ & 0.712 \\
activities. & \\
I do not consider the duty of the physiotherapist & 0.681 \\
to guide patients about sexual activities. & \\
I am prepared to discuss any issue related to & 0.598 \\
sexual activity with patients of both sexes. & \\
The knowledge acquired in my graduation & \\
provides me security to discuss issues related & 0.597 \\
to sexuality. & \\
I consider that it is ethical to deny treatment to \\
patients with abnormal sexual behaviors. \\
$\begin{array}{l}\text { I do not mind if the patient has an erection or } \\
\text { became sexually aroused during treatment }\end{array}$ \\
because, commonly, I have my escape \\
strategies. \\
$\begin{array}{l}\text { I believe that sexual dysfunction may be } \\
\text { due to a primary disease and therefore the } \\
\text { physiotherapist should conduct the treatment. }\end{array}$ \\
$\begin{array}{l}\text { I consider that the physiotherapist should } \\
\text { provide comprehensive treatment to patients } \\
\text { including sexual dysfunction treatment. }\end{array}$ \\
\hline
\end{tabular}

With the final version of the instrument with 37 items, analysis of internal consistency was performed through Cronbach's alpha value of 0.861 for the entire instrument. The same analysis was performed for each domain, indicating good homogeneity among dimensions.
The clarity analysis showed that question "Specific terms such as dyspareunia, vaginismus, anorgasmia etc." showed average of 7.5 both in Knowledge and Comfort domains, being excluded from the instrument. All other items of the scale were kept because they showed mean above 8.5 .

\section{Discussion}

Previous studies have reported the importance of working knowledge, comfort and attitude towards sexuality in the training of undergraduate students (8, $24,25)$; however, no comprehensive instrument validated with all these variables has been used till date.

From literature, knowledge, comfort and attitude were defined as basic dimensions for understanding how Physiotherapy students deal with human sexuality (18). In this context, knowledge means to express opinions with the acquired understanding of a certain fact, while comfort translates into a state that can be of tranquility, relief or calmness (26). Attitude denotes organized and coherent way of thinking and feeling that will lead to a reaction in relation to any person, object or event (27).

The choice of behavioral aspects listed in SKCAPS was based on the list of educational goals of our institutions and our experience as authors and educators in the health area. Although these behaviors also serve to assess students from any other health area, the items proposed here have higher suitability to physiotherapists due to the specificity of the activity that requires more intimate contact between patient and professional.

The first version of the instrument was submitted to content validation by experts. The three questions excluded from this process reflected lack of agreement regarding consistency, representativeness, relevance and clarity among judges. In relation to the exclusion of questions "fertility procedures" and "professional methods to work with sexual rehabilitation", it was understood that they require a high level of knowledge about such methods, which commonly are not part of everyday curriculum. In the last item "I feel very uncomfortable if the patient touches my breast or other intimate part" presented problems in relation to the dimension it was included (attitudes), as well as the nonspecific way the question was semantically built, causing disagreement among judges. 
The proposed scale, final version composed of 37 items, was responded by physiotherapy students from various stages of four different educational institutions, one public and three private universities. The analysis showed that the scale is valid and showed high reliability and clarity values, indicating that the instrument is accurately measuring what has been proposed, being reproducible in different academic centers and phases of the physiotherapy course. These basic features are essential to build pedagogical instruments in clinical practice (28).

The data obtained from the future application of SKCAPS to measure attitudes and perceptions may contribute to the early identification of behavioral trends of Physiotherapy students towards aspects considered challenging for this profession, providing subsidies for educational and institutional measures to strengthen desirable attitudes and correction in the case of detecting deviations from what would be expected.

However, investigations of this nature may require other theoretical instruments, since measuring instruments often do not exhaust the entire conceptual framework related to issues involved in the field of education and health.

In a study of Pynor et al. (29) with 333 Physiotherapy undergraduate students, it was observed that more than half of them did not receive adequate information during academic background. This result makes clinical practice uncomfortable and undermines professional management. Thus, acquiring knowledge about human sexuality is extremely important for professionals to feel safe and comfortable to treat their patients $(6,26,30)$.

Undergraduate Monitoring Programs or tutorials are practical examples. They aim to assist the theoretical and practical development of a given subject aimed to improve the teaching-learning process and the creation of conditions for the improvement of skills related to ethics for future professional behavior. That way the undergraduate student can minimize the perception towards conflicting and embarrassing situations, increase security in everyday practical situations, improve interpersonal relationships and exercise responsibility in the work environment.

This instrument can be understood as a way of strengthening of the creation, organization and dissemination cycle of knowledge, with great social contribution, since it is one of the factors that can influence and accelerate the pace and reflections about how people relate to each other and to the others. Thus, over time, it can enhance the construction of new professional competencies (knowledge, skills and attitudes), expected in most political pedagogic projects, since the hands are the physiotherapist's work object and the body the receptor of this action.

\section{References}

1. Vaz RA, Nodin NA. Importância do exercício físico nos anos maduros da sexualidade. Aná Psicológica. 2005;23(3):329-39.

2. Santos LV, Campos MPA, Ribeiro AO, de Mattos MCT. Sexualidade humana: nível de conhecimento dos acadêmicos de Enfermagem. Esc Anna Nery Rev Enferm. 2007;11(2):303-6.

3. Guilford JP. Psychometric methods. New York: Mc Graw-Hill; 1954.

4. Barrett M, McKay A. Training in sexual health and STD prevention in Canadian medical schools. Can J Hum Sex. 1998;7(4):305-20.

5. Pupulim JSL, Sawada NO. 0 cuidado de enfermagem e a invasão da privacidade do doente: uma questão ético-moral. Rev Lat-Am Enfermagem. 2002;10(3):433-8.

6. Jones MK, Weerakoon P, Pynor RA. Survey of occupational therapy student's attitudes towards sexual issues in clinical practice. Occup Ther Int. 2005; 12(2): 95-106.

7. Alencar RA, Ciosak SI, Bueno SMV. Formação do acadêmico enfermeiro: necessidade da inserção curricular da disciplina de sexualidade humana. Online Braz J Nurs. 2010 [cited 2015, May 28];9(2). Available from: http://www.objnursing.uff.br/index.php/ nursing/article/view/j.1676-4285.2010.2991/669

8. Gir E, Nogueira MS, Pelá NTR. Sexualidade humana na formação do enfermeiro. Rev Lat-Am Enfermagem. 2000;8(2):33-40.

9. Mandú ENT. Consulta de enfermagem na promoção da saúde sexual. Rev Bras Enferm. 2004;57(6):729-32.

10. Colicchio D, Passos ADC. Comportamento no trânsito entre estudantes de medicina. Rev Assoc Med Bras. 2010;56(5):535-540. 
11. Rozmus CL, Evans R, Wysochansky M, Mixon D. An analysis of health promotion and risk behaviors of freshman college students in a rural southern setting. J Pediatr Nurs. 2005;20(1):25-33.

12. Tamim H, Terro A, Kassem H, Ghazi A, Khamis TA, Hay MMA, et al. Tobacco use by university students, Lebanon, 2001. Addiction. 2003;98(7):933-9.

13. Chipchase LS, Buttrum PJ, Dunwoodie R, Hill AE, Mandrusiak A, Moran M. Characteristics of student preparedness for clinical learning: clinical educator perspectives using the Delphi approach. BMC Med Educ. 2012;12:112.

14. Thomson D, Hilton R. An evaluation of students' perceptions of a college-based programme that involves patients, carers and service users in physiotherapy education. Physiother Res Int. 2012;17(1):36-47.

15. Colares MFA, Troncon LEA, Figueiredo JFC, Cianflone ARL, Veronese MLR, Piccinato CE, et al. Construção de um instrumento para avaliação das atitudes de estudantes de medicina frente a aspectos relevantes da prática médica. Rev Bras de Educ Med. 2002;26(3):194-203.

16. Brasil. Ministério da Educação. Instituições de Educação Superior e Cursos Cadastrados. Brasília: Ministério da Educação; 2013 [cited 2013, Mar 20]. Available from: http://emec.mec.gov.br

17. Conselho Federal de Fisioterapia e Terapia Ocupacional. Quantitativo de profissionais cadastrados. Brasília: Cofito; 2013 [cited 2013, Mar 19]. Available from: http://www.coffito.org.br/faqs/faq.asp

18. Kendall M, Booth S, Fronek P, Miller D, Geraghty T. The development of a scale to assess the training needs of professionals in providing sexuality rehabilitation following spinal cord injury. Sex Disabil. 2003;21(1):49-64.

19. Pasquali L. Princípios de elaboração de escalas psicológicas. Rev Psiquiatr Clin. 1998;25(5):206-13.
20. Polit DF, Beck CT, Owen SV. Is the CVI an acceptable indicator of content validity? Appraisal and recommendations. Res Nurs Health. 2007;30(4):459-67.

21. Alexandre NMC, Coluci MZO. Validade de conteúdo nos processos de construção e adaptação de instrumentos de medidas. Ciênc Saúde Coletiva. 2011;16(7):3061-8.

22. Pasquali L. Psicometria: teoria e aplicações. Brasília: Editora Universidade de Brasília; 1997.

23. Dancey CP, Reidy J. Statistics without maths for Psychology: using SPSS for Windows. London: Prentice Hall; 2005.

24. Kong SKF, Wu LH, Loke AY. Nursing student's knowledge, attitude and readiness to work for clients with sexual health concerns. J Clin Nurs. 2008;18(16):2372-82.

25. Levine SB, Scott DL. Sexual education for psychiatric residents. Acad Psychiatry. 2010;34(5):349-52.

26. Hamilton J. Comfort and the hospitalized chronically ill. J Gerontol Nurs. 1989;15(4):28-33.

27. Lambert WW, Lambert WE. Psicologia social. Rio de Janeiro: Zahar; 1972.

28. de Vet HCW, Terwee CB, Bouter LM. Current challenges in clinimetrics. J Clin Epidemiol. 2003;56(12):1137-141.

29. Pynor R, Weeraboon P, Jones MK. A preliminary investigation of physiotherapy student's attitude towards issues of sexuality in clinical practice. Physiotherapy. 2005;91(1):42-8.

30. Lima MCP, Cerqueira ATAR. Crenças sobre sexualidade entre estudantes de Medicina: uma comparação entre gêneros. Rev Bras Educ Med. 2008;32(1):49-55.

Received: $11 / 26 / 2013$

Recebido: 26/11/2103

Approved: 02/27/2015

Aprovado: 27/02/2015 


\section{Annex 1}

\section{Scale of Knowledge, Comfort and Attitudes of Physiotherapy Undergraduate Students towards Human Sexuality}

1) Indicate on a scale from 1 (no knowledge) to 4 (excellent knowledge), your current level of knowledge on the topics below. And on a scale from 1 (not comfortable at all) to 4 (very comfortable) how much you feel comfortable to start a conversation about the same topics:

\begin{tabular}{|c|c|c|c|c|c|c|c|c|}
\hline & \multicolumn{4}{|c|}{ Knowledge } & \multicolumn{4}{|c|}{ Comfort } \\
\hline & None & Little & Good & Excellent & None & Little & Good & Excellent \\
\hline Sexual anatomy and physiology & 1 & 2 & 3 & 4 & 1 & 2 & 3 & 4 \\
\hline $\begin{array}{l}\text { Accessories, devices and drugs to } \\
\text { achieve erections and / or vaginal } \\
\text { lubrication }\end{array}$ & 1 & 2 & 3 & 4 & 1 & 2 & 3 & 4 \\
\hline $\begin{array}{l}\text { Risks of sexual activity for the } \\
\text { cardiovascular system }\end{array}$ & 1 & 2 & 3 & 4 & 1 & 2 & 3 & 4 \\
\hline $\begin{array}{l}\text { Sexuality with physical disability } \\
\text { (paraplegia, hemiplegia etc.) }\end{array}$ & 1 & 2 & 3 & 4 & 1 & 2 & 3 & 4 \\
\hline Sexuality during adolescence & 1 & 2 & 3 & 4 & 1 & 2 & 3 & 4 \\
\hline Sexuality during pregnancy & 1 & 2 & 3 & 4 & 1 & 2 & 3 & 4 \\
\hline Sexuality during Puerperium & 1 & 2 & 3 & 4 & 1 & 2 & 3 & 4 \\
\hline Sexuality during menopause & 1 & 2 & 3 & 4 & 1 & 2 & 3 & 4 \\
\hline Sexuality with urinary incontinence & 1 & 2 & 3 & 4 & 1 & 2 & 3 & 4 \\
\hline $\begin{array}{l}\text { Methods for male and female } \\
\text { contraception }\end{array}$ & 1 & 2 & 3 & 4 & 1 & 2 & 3 & 4 \\
\hline $\begin{array}{l}\text { Techniques and resources to work with } \\
\text { sexual rehabilitation }\end{array}$ & 1 & 2 & 3 & 4 & 1 & 2 & 3 & 4 \\
\hline
\end{tabular}

2) Evaluate on a scale from 1 (no discomfort) to 4 (high discomfort) how would you feel uncomfortable in each situation below:

\begin{tabular}{lcccc}
\hline Discomfort & $\begin{array}{c}\text { No } \\
\text { discomfort }\end{array}$ & $\begin{array}{c}\text { Little } \\
\text { discomfort }\end{array}$ & $\begin{array}{c}\text { Intermediate } \\
\text { discomfort }\end{array}$ & $\begin{array}{c}\text { High } \\
\text { discomfort }\end{array}$ \\
\hline $\begin{array}{l}\text { How would you feel if you noted that the patient of the opposite } \\
\text { sex had an erection or became sexually aroused during treatment? }\end{array}$ & 1 & 2 & 3 & 4 \\
$\begin{array}{l}\text { How would you feel if you noted that the patient of the same sex } \\
\text { had an erection or became sexually aroused during treatment? } \\
\begin{array}{l}\text { How would you feel if a patient of the opposite sex touched your } \\
\text { breast / penis or other intimate part? }\end{array}\end{array}$ & 1 & 2 & 3 & 4 \\
$\begin{array}{l}\text { How would you feel if a patient of the same sex touched your } \\
\text { breast / penis or other intimate part? }\end{array}$ & 1 & 2 & 3 & 4 \\
$\begin{array}{l}\text { How would you feel if a patient of the opposite sex invited you for } \\
\text { a date? }\end{array}$ & 1 & 2 & 3 & 4 \\
$\begin{array}{l}\text { How would you feel if a patient of the same sex invited you } \\
\text { for a date? } \\
\begin{array}{l}\text { How would you feel if a patient revealed abnormal sexual } \\
\text { behaviors such as sex with dead or animals etc. }\end{array}\end{array}$ & 1 & 2 & 3 & 4 \\
\hline
\end{tabular}


3) Check how much you agree or disagree with the following statements:

\begin{tabular}{|c|c|c|c|c|c|}
\hline Attitudes & $\begin{array}{l}\text { Totally } \\
\text { agree }\end{array}$ & $\begin{array}{l}\text { Partly } \\
\text { agree }\end{array}$ & $\begin{array}{l}\text { I am not } \\
\text { sure }\end{array}$ & $\begin{array}{l}\text { Partly } \\
\text { disagree }\end{array}$ & $\begin{array}{c}\text { Totally } \\
\text { disagree }\end{array}$ \\
\hline \multicolumn{6}{|l|}{ a) I do not mind if the patient has an erection or } \\
\hline $\begin{array}{l}\text { became sexually aroused during treatment because, } \\
\text { commonly, I have my escape strategies. }\end{array}$ & 1 & 2 & 3 & 4 & 5 \\
\hline $\begin{array}{l}\text { b) I am prepared to discuss any issue related to sexual } \\
\text { activity with patients of both sexes. }\end{array}$ & 1 & 2 & 3 & 4 & 5 \\
\hline $\begin{array}{l}\text { c) The knowledge acquired in my graduation provides } \\
\text { me security to discuss issues related to sexuality. }\end{array}$ & 1 & 2 & 3 & 4 & 5 \\
\hline $\begin{array}{l}\text { d) I do not consider the duty of the physiotherapist to } \\
\text { guide patients about sexual activities. }\end{array}$ & 1 & 2 & 3 & 4 & 5 \\
\hline $\begin{array}{l}\text { e) I consider that it is duty only of physicians and / or } \\
\text { nurses to guide patients about sexual activities. }\end{array}$ & 1 & 2 & 3 & 4 & 5 \\
\hline $\begin{array}{l}\text { f) I consider that it is ethical to deny treatment to } \\
\text { patients with abnormal sexual behaviors }\end{array}$ & 1 & 2 & 3 & 4 & 5 \\
\hline $\begin{array}{l}\text { g) I believe that sexual dysfunction may be due to a } \\
\text { primary disease and therefore the physiotherapist } \\
\text { should conduct the treatment. }\end{array}$ & 1 & 2 & 3 & 4 & 5 \\
\hline $\begin{array}{l}\text { h) I consider that the physiotherapist should provide } \\
\text { comprehensive treatment to patients including sexual } \\
\text { dysfunction treatment. }\end{array}$ & 1 & 2 & 3 & 4 & 5 \\
\hline
\end{tabular}

\section{Calculation}

Domains Knowledge, Comfort and Discomfort: by means of the sum of questions obtaining scores of each domain, indicating that the higher the score, the higher the knowledge, comfort and discomfort.

Domain attitudes: questions $a, b, c, g$, h should be scored in reverse where $1=5 ; 2=4 ; 3=3 ; 4=2 ; 5=1$. The sum of questions indicated that the higher the score, the more positive is the 